\title{
Obituaries
}

\section{Rosentyl Griffiths}

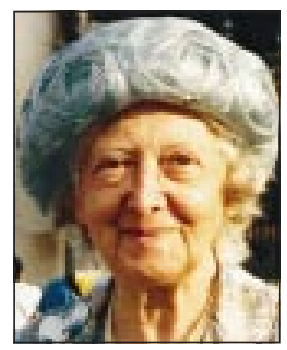

Former general practitioner Cardiff $(b$ Dowlais, Mid-Glamorgan, 1903; $q$ Cardiff 1929; FRCGP), d 28 February 1999. Rose always said that she entered medicine because of the several cures her grandfather was reputed to have had for skin cancer. He provided his daughter with an interest in the art of curing, and she passed this on to her daughter. She started in practice in 1931 and was joined by her sister, Bryneilen, in 1933, but after the introduction of the NHS they decided to remain totally in private practice as they thought that they would be able to devote more time to their patients. Rose maintained a keen interest in medicopolitics, being past chairman of the Cardiff division of the BMA and of the Welsh council, and a representative at BMA annual meetings for 20 years. She was made a fellow of the BMA in 1979. Her diminutive figure belied an enormous amount of energy, evidenced by study tours to Russia, an air trip round the world, and attendance at seven BMA overseas meetings. Her sister died in 1991. [RALPH A A R LAWRENCE]

\section{Robert Barrie Niven}

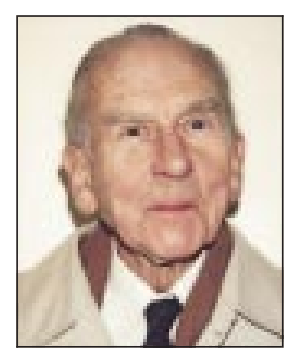

Former consultant physician King George Hospital, Ilford ( $b$ South Africa 1910; $q$ Oxford/King's College Hospital 1937; FRCP), died from a dissecting aortic aneurysm having enjoyed a short walk earlier in the day on 16 February 1999. He came to
England as a Rhodes Scholar and intended to return to South Africa as a medical missionary, but he married Edith, an ear, nose, and throat surgeon, and they decided to make their careers in Britain. During the war he was a medical specialist with the Royal Air Force in Italy, Austria, and Egypt. When his wife was injured in a car crash she turned her energy to work for the deaf, founding and directing the Nuffield Hearing and Speech Centre. Robert became involved in her work, editing her book, Learning to Hear, and accompanying her on a lecture tour of the United States. On her death he endowed the Edith Whetnall Lecture at the Royal Society of Medicine. With his second wife, Anne, he enjoyed touring in their motor caravan and gardening. After retirement he became a member and then chairman of the Pensions Appeals Tribunals. He cherished to the end his deep Christian faith. He leaves his second wife, Anne. [Tom Dunn]

\section{John Godfrey Peacock}

Former consultant anaesthetist ( $b$ 1916; $q$ St Thomas's 1937; FRCA), $d 23$ March 1999. He served in the Royal Army Medical Corps during the war in France and then in India, the Maldives, and Ceylon. He then spent several years in east Africa, first with the ground nut scheme as an anaesthetist and chief medical officer for Kongwa Hospital and then as consultant anaesthetist with the colonial medical service in Dar es Salaam. He returned to England in 1963 and joined the Dulwich and Camberwell Group of Hospitals at King's College Hospital. He had a year's exchange in the United States and after he retired returned to work in New York for a time. John worked tirelessly for the abolition of animal quarantine and for pet passports and was delighted that this will soon be on the statute books. He leaves a wife, Jessica; a daughter; four grandchildren; and seven great grandchildren. [ElizABETH ButLeR]

\section{James Norman Swainston}

Former general practitioner Hebburn on Tyne ( $b$ South Shields 1913; $q$ Durham 1935), died from bronchial pneumonia and ischaemic heart disease on 8 March 1999. When he first entered general practice as an assistant he was chauffeur driven in an Austin 7. During the war he served with the Highland Light Infantry in France and India. While in practice he was also anaesthetist and radio- logist at the local hospital, using the dark room for his photography. He was deeply involved in the advances in health care, including the introduction of the first general practitioner training scheme in 1965 . He served on many committees, being chairman of the joint committee of North of England Local Medical Committees for 25 years, and was a keen Rotarian and Probus member, receiving the Paul Harris Award in 1998. He retired in 1976 to look after his wife, who died in 1989, two weeks after his third myocardial infarction. He then travelled widely, in the United Kingdom and abroad, and died a few days after a trip to Majorca. He leaves four children (one a doctor) and eight grandchildren (five in medicine). [D G SwaInston]

\section{Robert George Whitelaw}

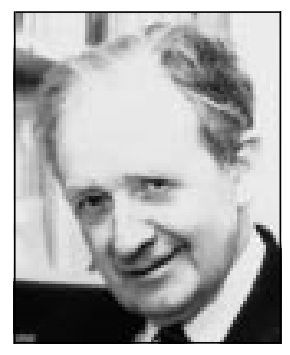

Former consultant obstetrician and gynaecologist West Fife Group of Hospitals $(b$ Motherwell 1913; $q$ Glasgow 1942; MD (with commendation), MRCOG), died from ischaemic heart disease on 8 March 1999. He went to university to do a degree in English but soon regretted that he had not entered the medicine faculty. So after completing an arts degree he won a second scholarship to study medicine. During the second world war he served as a surgeon lieutenant with the Royal Naval Volunteer Reserve and for nine months was attached to a group of seven ships which sailed in arrowhead formation ahead of the Russian convoys. Three were torpedoed. He did his MD on research into ovarian activity after hysterectomy. In 1969 he was delighted to be appointed deputy lieutenant of the County of Fife and an external examiner to the University of Edinburgh. When he retired from practice he was appointed honorary sheriff, and he was a past president of the Fife branch of the BMA and of the West Fife Medical Society. He leaves a wife, Cicely; a son (a professor in paediatrics); and four grandchildren. [R G WHITELAW] 